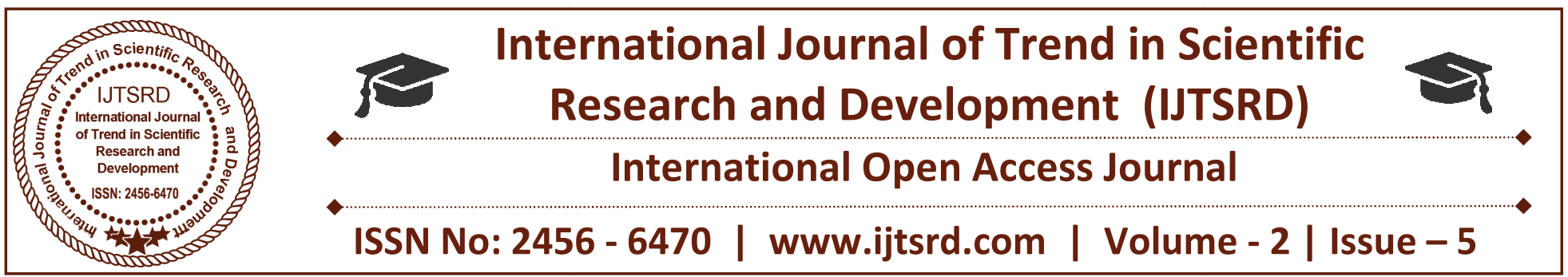

\title{
Reforming Indian Political System and Rating of Politicians : The Voter's Perspective
}

\author{
Amitabh Bhargava ${ }^{1}$, Harsh Purohit ${ }^{2}$ \\ ${ }^{1}$ Research Scholar, ${ }^{2}$ Professor (Management), \\ Banasthali Vidyapith, P.O Banasthali Vidyapith, Vanasthali, Rajasthan, India
}

\begin{abstract}
The formation of Democracy in India was a major movement after independence for building the fair political system defined as "Of the People, For the People and By the People". But the Citizens of India witness corruption in Indian Political System which is growing gradually and dangerously and has become a CANCER for the Nation. The citizens are now become awake for their rights and also ready to come forward for the same. The need of the day is to reform the ongoing Indian Political System by rating our politician's competency. Such a system is possible through Holistic Electoral Competency Rating
\end{abstract} (HECR).

The objective of this paper is to analyze the voter's view on rating or politicians and to make them understand and believe on the rating system across India. The purpose of this paper is not to blame our existing political system or to form a new political structure, but the outcome of the study will help to develop the Electoral Rating System, so that a voter can measure a politician on specified HECR parameters and help voter to vote rightly.

India/Bharat/Hindustan, the name of the country, has earned the status of strongest democratic republic in the world. August 15, 1947, the day when India was celebrating the independence from British rule of more than 300 years.

Free \& Fair Election in a Democratic Republic was the foremost objective after Constitution came in force and various committees were appointed to advise the government in matters relating to election and also control the malpractices which were prevalent during the British period. The Constitution of India preserved the rights of every voter. The constitutional provisions provided protection as well as freedom of choice to every voter [1]. Politics in India was once a moral act, but it has been observed that it has become full of scandals and because of the scandals the GDP is decreasing month on month/year on year, with a result, Indian economy is going down, the country is de-growing and the citizens are suffering. The list of scams from year 1947 to 2012 is indicating that the scams are gradually increasing in India year by year [22]:

Keywords: HECR, Democracy, Electoral system, Electoral Candidate, Reforming Indian political system

\section{INTRODUCTION}

Your beliefs become your thoughts, your thoughts become your words, your words become your actions, your actions become your habits, your habits become your values, your values become your destiny

- Mahatma Gandhi

"It is a telling example of India's old politics of cronyism and corruption catching up with new urgencies of transparency, fairness and institutional reform."

- Times of India, Al Jazeera (2012)

There is less passion and honesty towards nation than before. The loss of trust in politics and depoliticisation due to increasing role of finance, exploitation of electorate (on the basis of caste and 
religion), switching political parties, criminalization of politics, corruption and other such problems have weaken our democratic structure. Further, we the citizens of India, has witnessed that the way the political parties are doing election campaigning is itself a cause of worry. The politicians openly indulge in vote bank politics. They target the vulnerable poor population which represents the $60 \%$ of our population. As a result of which wrong people are elected who are just interested in promoting their own welfare.

We can see the present situation of voters who have no choice to elect better among the candidates for their constituency. Certain reforms should be brought such that the candidate stood for election shouldn't have at-least a single case filed against him. "Corruption being snake in the grass" and apart of these entire curses our golden birds still are waiting for a roar by responsible and talented youth.

Here is the need is reforming the Indian Political System. Sukhdev Singh (2012) also raised this issue in his article on "Electoral reforms in India" [2]. This article deals with the electoral reforms which can be introduced in India. The present electoral system in India has a lot of drawbacks which need to be set right for free and fair elections in the country.

The apprehensions have no end but are not convincing enough to deter someone from making a modest start. Armstrong and Graefe (2010) identified 60 variables [3] but the purpose was not rating before elections but rather to prepare an index to explain outcome of US Presidential elections.

\section{The Holistic Electoral Competency Rating (HECR)} [4] is a rating system that benchmarked the index to rate the qualities of great political leaders and identifying entry level competencies. If the electoral reforms and rating suggested are carried out by the citizens and government sincerely, then we can feel proud of our democratic system and project our system as model to be followed by the other newly emerged democratic countries of the world.

\section{OBJECTIVES}

1. To evaluate attitude of Indian Citizens about need and process of HECR in India

2. To evaluate the possible alternatives and governance structure of rating agencies that should rate the politicians.

\section{REVIEW OF LITERATURE}

Garg Rishab, Sneha Ritwik (2012) talked about the electoral reforms as an approach to effective democracy in India [1]. Sanjay Kumar (2002) stated that the attempt to reform the electoral system is a welcome move. However, the current proposals on candidates' disclosures of various kinds do not appear to be well-constructed and the bill includes ambiguities which are open to misinterpretation. It is perhaps more important immediately to strengthen the system of preparing electoral rolls and allowing public access to them [2].

Armstrong and Graefe (2010) used the take-the-best heuristic to develop a model to forecast the popular two party vote shares in U.S. presidential elections. The take-the-best heuristic generated accurate forecasts based on voters' perceptions on how the candidates will handle the single most important issue facing the country [3].

Purohit (2011) proposed the Educationist perspective on rating the politicians through Holistic Electoral Competency Rating (HECR). He stated that all facets of Holistic development of our country are affected by role played by a value chain involving spiritual, social \& market values. Even though the role of state (Government) seemed to be lesser in market driven economy, the need to catalyze and be a guiding force for various facets of Holistic development cannot be underestimated. He proposed the rating for a politician just like applicable for an IPO or CP or any other Debt instrument or Corporate Governance or Universities. He suggested implementing such a system in India where the citizen can rate a politician [4]. They also highlighted upon the conditions under which index models are useful as a reply to Bio-index Commentaries [5] and tested the index method for Predicting Elections from Biographical Information about Candidates [6].

Cuzán, A. G. \& Bundrick, C. M. (2009) articulated an idea for predicting presidential elections with equallyweighted regressors in Fair's equation and the fiscal model [7]. Simonton Dean K. (1993) discussed what political psychology might have to offer in making it more likely that the best leaders might become Presidents of the United States [8]. Petrocik, J. R. (1996), proposed "Issue ownership theory" of voting that emphasized the role campaigns in setting the criteria for voters to choose between candidates [9]. 
Lau, R. R. \& Redlawsk, D. P. (1997) proposed a system for the voter to vote "correctly". They stated that the average voter falls far short of the prescriptions of classic democratic theory in terms of interest, knowledge, and participation in politics. [10]. Nicholas R. Miller (1980) proposed a new Solution Set for Tournaments and Majority Voting with special emphasize on Further Graph-Theoretical Approaches to the Theory of Voting [11]. Wlezien, C. (2005) commented on the salience of voters on political issues. [12].

Matthew Atkinson, Ryan D. Enos Seth \& J. Hill (2009) examined the candidate faces and election outcomes in their paper [13]. Dawn Brancati (2011) investigated in his paper, the effectiveness of an important form of democracy promotion, electoral monitoring, in terms of its impact on citizens' perceptions of democracy and their subsequent participation in politics through a field experiment in Kosova [14].

T T Ram Mohan (2007) also stressed upon reforming Indian politics in his column in The Economic Times. He raised some burning issues like Criminalization of politics, the absence of state funding of elections, an increasingly politicized bureaucracy, a moribund legal system [15].

The papers reviewed above motivate the researcher to build a rating system in India for reforming our Political System. New electoral monitors in addition to existing monitors proposed by Dawn Brancati (2011) are to be identified. Also key variables suggested by Armstrong and Graefe (2010) for US elections are benchmarked for identifying new variables for entry level competencies of a politician. New parameters will be added with existing HECR parameters in order to perform holistic rating of an electoral candidate.

\section{METHODOLOGY}

Feasibility Study is an important phase of any system. Here the Survey method is used to carry out the study to get the details from the respondents of different focus groups. The research instruments intended for the study are questionnaires, web based tools, interviews, discussion groups, social networking and case studies. Questionnaire and Schedule is designed after careful analysis. Researcher administered questionnaires are planned for this study as this method facilitates the collection of data with proper clarification of questions, if required. Further, it ensures a higher response rate. Various methodologies like graphs, matrixes, comparison tables for analyses of responses of various questions are used after questionnaire survey. The research will be under descriptive study which will include large population studies in which data on lots of different variables will be collected. Questionnaire has undergone pilot study and cronbach alpha testing.

\section{MOTIVATION OF RESEARCH}

This paper is based upon the Proposed HECR model by Purohit, 2011. This model covers the parameter like Awareness Parameters, Track Record, personal \& family conditions, Opinion of voters, Vision, Mission \& Execution and affirmation of electoral candidate

A candidate may be asked to submit about all above in writing and than face an interview. The final report should bear his signature assuring all above is true \& valid. The above can be called as HECR (Holistic Electoral Competency Rating). The HECR parameters and weightage may vary based on:

1. New Candidate

2. Old Candidate (Winner/Looser earlier)

3. Candidate seeking a ministerial portfolio (needs assessment about awareness of ministry as well)

For new candidates the weight age can be $30 \%$ each for $\mathbf{A}$ and $\mathbf{B}$ while $20 \%$ for $\mathbf{C}$ and $10 \%$ each for $\mathbf{D}$ and E. While for old candidates the weight age can be different. The score obtained by candidates can be indexed and compared, and a rating can be assigned based on index value.

\section{PROPOSED ENHANCED HECR SYSTEM FOR RATING OF POLITICIANS}

The focus of this study is to understand the requirement of rating of politicians and changes in existing electoral system with voter's perspective. The data has been collected through questionnaire by using different parameters. The questionnaire contained total 90 questions in 9 different categories like personal profile, voter's insight, Voter's view on Democracy, Factors influencing voters', Attributes of a leader-Voter's perspective, Voter's opinion poll and Rating of Politicians-Before and After Election.

The data was collected from 1232 citizens from 27 different states including 2 NRIs in USA and Republic of Mauritius. 


\section{SAMPLING}

Convenience sampling and random sampling shall be used to get information from respondents. The sample comprised of 1232 responders (14 type of professions, 4 age-groups and $71 \%$ males and $29 \%$ females as criteria for classification) located throughout India (predominantly limited to netizens i.e. internet users outside Rajasthan/NCR). Study covered citizens from four main regions of India 37\% from Jaipur, 15\% rest cities of Rajasthan, 17\% from NCR Region and 32\% PAN India other than Rajasthan \& NCR. The responses were collected for preliminary feel of Indians about the research theme.

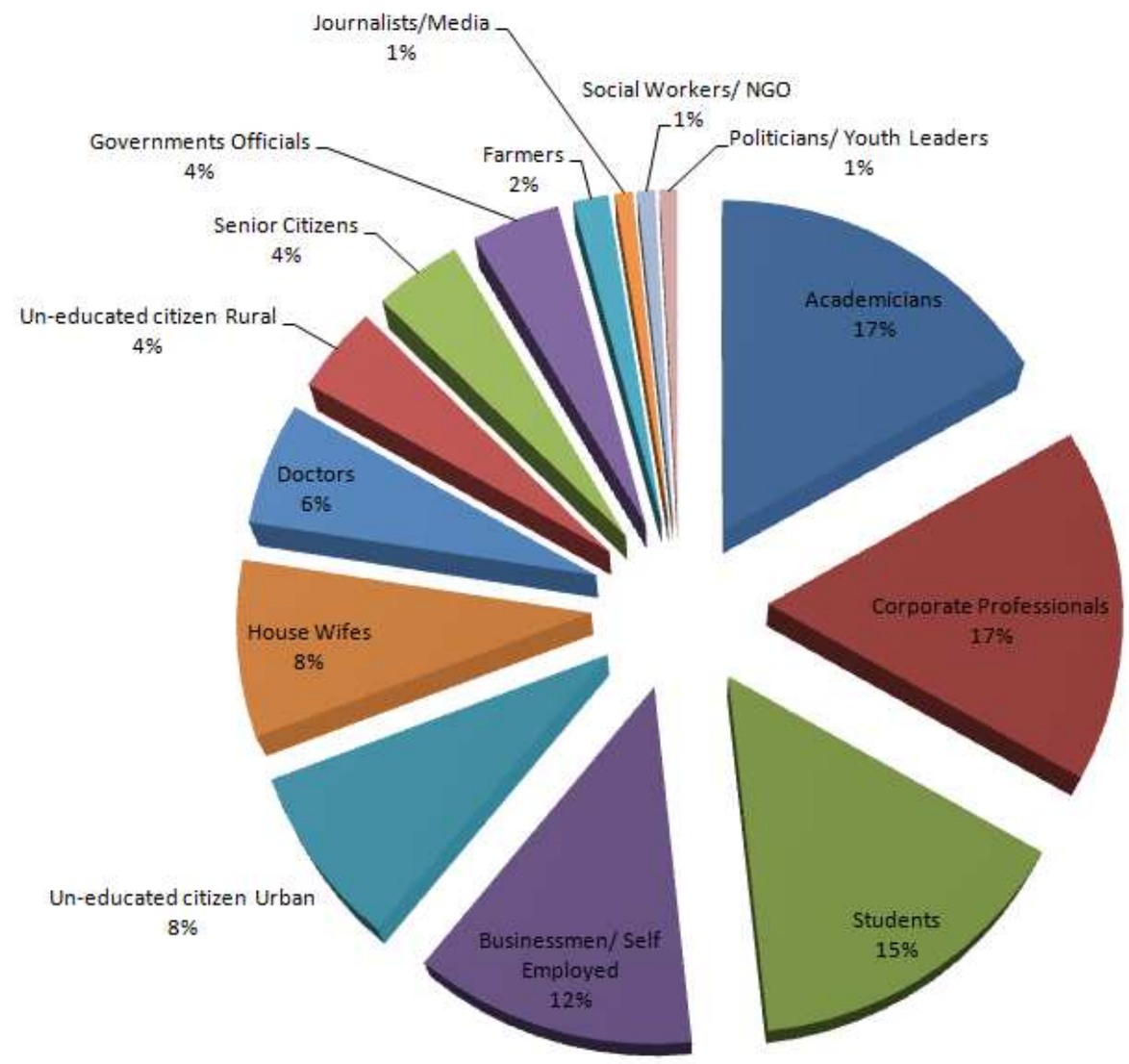

Figure 1: Percentage sample collection from different category of citizens

\section{Tools of Data Collection}

The research is under descriptive study which includes large population studies in which data on lots of different variables are collected.

For this study, the Primary and Secondary sources of data collection are as under.

Primary Sources: Citizens of India who are eligible to vote.

Secondary Sources: Constitution of India, Govt. of India Websites, Annual reports, Books, Research Papers published in journals, Online Blogs, Articles, and Social Forums etc.

The questionnaire was developed on the basis of Proposed HECR by Purohit, 2011 published in Times of India. This was the Research Model for this study.
The parameters suggested were called HECR (Holistic Electoral Competency Rating):

$>$ Awareness Parameters

$>$ Track Record, personal \& family conditions

Vision, Mission \& Execution

$>$ Opinion

$>$ Affirmation

To highlight this study, we have prepared first draft of questionnaire and included around 70 questions. The pilot study was conducted for 70 respondents. Based upon their feedback and expert opinion and cronbach alpha testing we have included around 27 questions comprises of 89 sub questions.

\section{Tools of Data Analysis}

The purpose of the data analysis and interpretation phase is to transform the data collected into credible evidence about the development of the intervention 
and its performance. This helps in aligning the desired "report" with the results of analysis and interpretation. In this research, both qualitative and quantitative analysis is involved. Grounded theory of qualitative research is used. Statistical analysis is conducted through factor analysis, Chit-Square Test, Analysis of Variance (ANOVA), Mean scores etc. using advanced Excel add-in tool for quick and accurate calculations. Analysis of variance (ANOVA) tests the hypothesis that the means of two or more populations are equal. ANOVA assess the importance of one or more factors by comparing the response variable means at the different factor levels.

\section{Significance of study}

In present scenario, the role of a citizen in selection of an electoral candidate is limited to the fundamental right of voting. The electoral candidate they've chosen decides the directions for the democratic environment. Why always the Indian political system should be blamed, though the citizens are also equally responsible. The need is, to aware the citizen for not only to use their right of vote but also to vote rightly. The research work is an attempt to develop the fair system for the rating of a politician with a special emphasize on self-realization and self-assessment among the citizens as well as politicians.

\section{Scope of Study}

The scope of this study is not limited to specific region as the study belongs to each citizen of India. For this study, we have categorized four regions Jaipur, Rajasthan, NCR and PAN India. Similarly the scope of study is limited to the citizens who is eligible to vote, aged more than 18 years and whose name is in voter's list. The study is carried out on each citizen ranging from academicians, corporate professions to house wives, un-educated citizens in rural or urban areas and also farmers.

\section{Limitations of study}

The limitation of this study is majorly the acceptability from the citizens of India that they should understand the value of their vote. They should also understand how the rating of politician would help them in selecting the right leader in their constituency. Following major limitations are identified in this study:

\section{Voter's View on Democracy}

The purpose of this section is to analyze the respondents view on Democracy like their agreement with the statement "The Democracy in India reflect 'Government of the people, for the people, and by the people'?"; we the Indians are proud to be the largest democratic country in the world; Ranking of different functionaries who are working well for the betterment of the nation; and Ranking of different challenges to the Democracy of our nation.

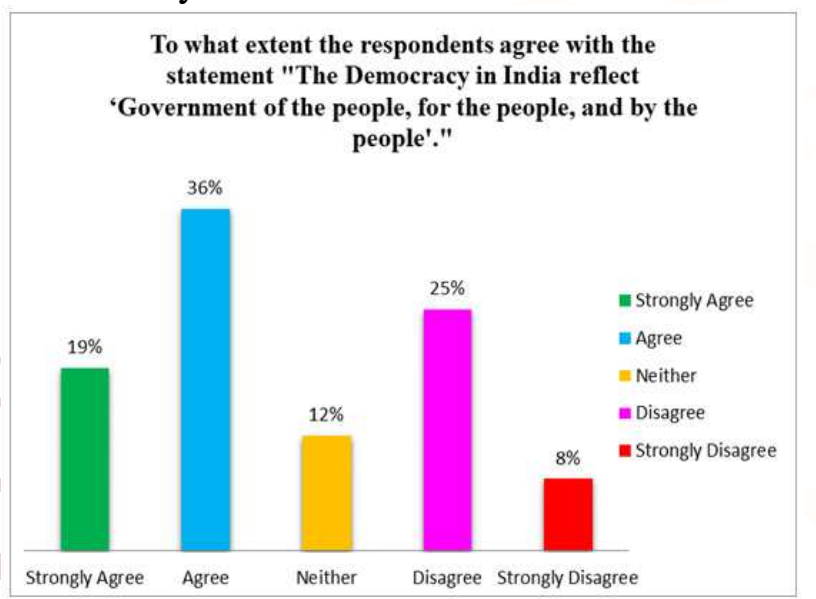

Fig. 2: Respondents agreement to the statement on Likert Scale

To what extent Respondents agree that we the Indians are proud to be the largest democratic country in the
world

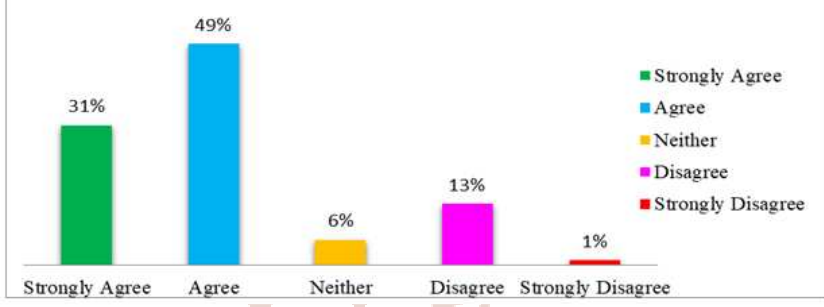

Fig. 3: Respondents agreement to the statement on Likert Scale

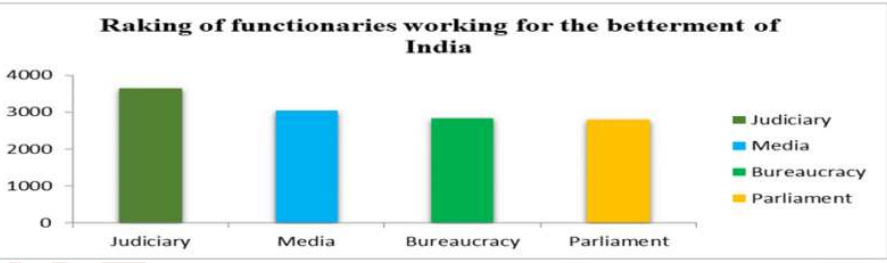

Fig. 4: Raking of functionaries working for the betterment of India

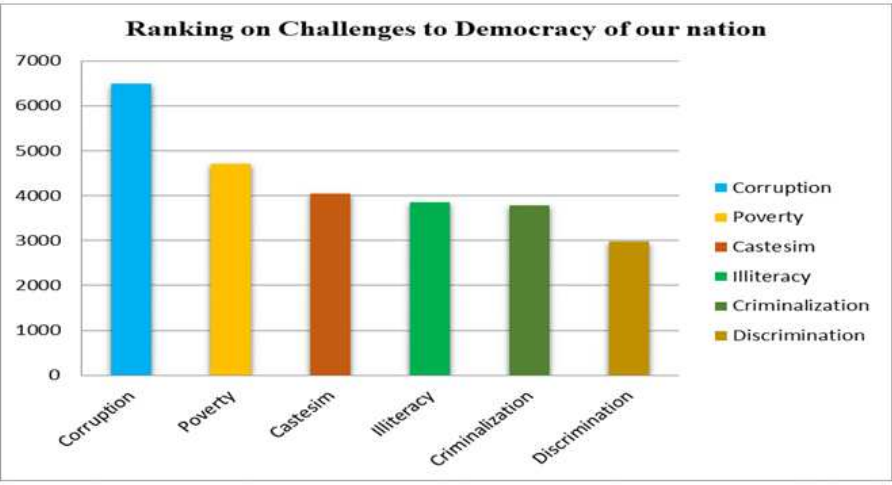

Fig. 4.5: Ranking on Challenges to Democracy of our nation 


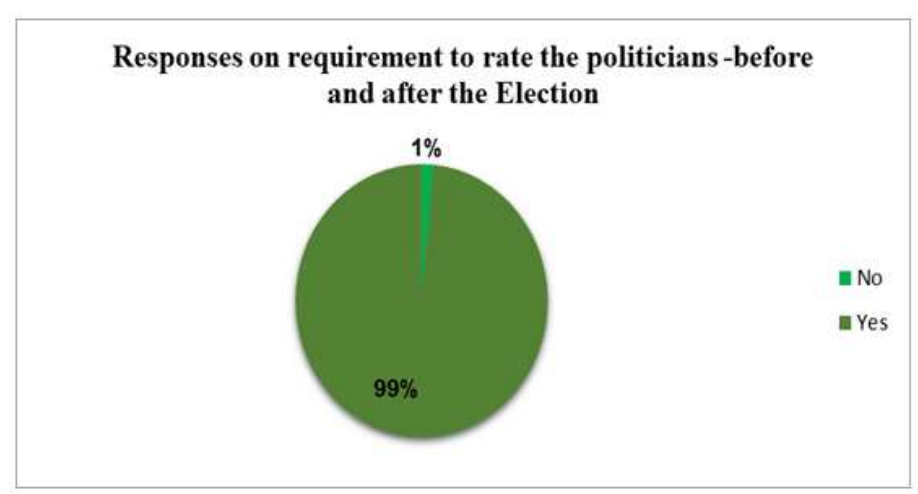

Figure 6: Response on requirement to rate the politicians-Before and After election

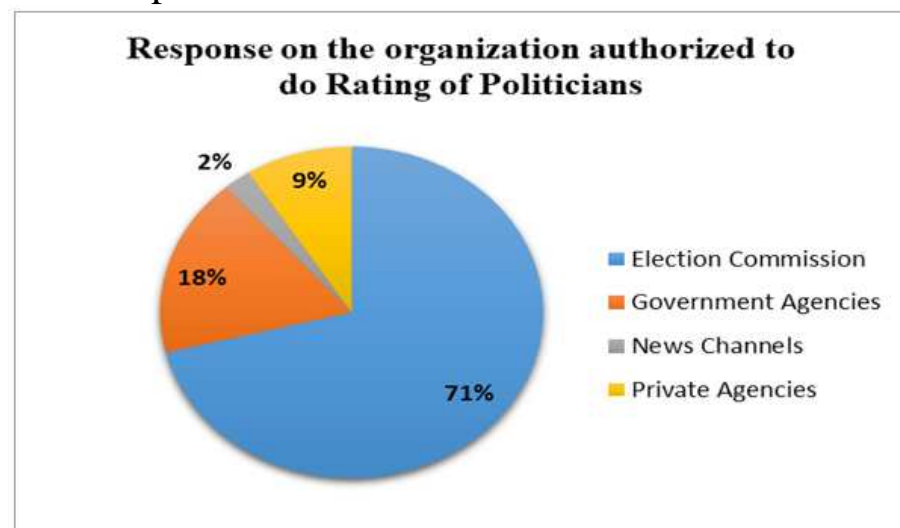

Fig. 7: Response on the organization authorized to do Rating of Politicians

\section{Conclusion}

Based upon the 1232 responses on requirement to rate the politicians before and after elections, majority of respondents i.e. $99 \%$ strongly agree and showed their positive response towards the need of rating process. Out of 1232 respondents, $71 \%$ satisfied with the functioning of Election commission of India for such rating. Total $18 \%$ respondents feel government agencies as another alternative. On the other hand, only $9 \%$ rated for private agencies and $2 \%$ for News Channels. Election commission should rate the politicians on different parameters of rating before and after elections. This rating system proposed in this research can be used to rate the politicians and publicize it on their portals.

As Majority of respondents agree upon the need of rating of politicians and feel that the Election Commission should publish a constitute-wise comparative analysis of contestants covering all major attributes. This rating system would help Election commission to publish such data before elections. As majority of respondents who are in favor of rating of politicians feel that the

\section{BIBLIOGRAPHY}

1. Rishab Garg \& Ritwik Sneha (2012), Electoral Reforms: An Approach To Effective Democracy, Legal Services India, ISBN No: 978-93-82417-019

2. Sanjay Kumar (2002), Reforming Indian Electoral Process, Economic and Political Weekly, Vol. 37, No. 34 (Aug. 24-30, 2002), pp. 3489-3491

3. Graefe, Andreas, Armstrong, Scott J. (2010), Predicting elections from the most important issue: A test of the take-the-best heuristic, Journal of Behavioral Decision Making; DOI: 10.1002/bdm.710

4. Harsh Purohit (2011), Educationist perspective on rating the politicians through Holistic Electoral Competency Rating (HECR), Online journal of www.indianmba.com

5. Andreas Graefe, J. Scott Armstrong (2011), Conditions under which index models are useful: Reply to Bio-index Commentaries, Journal of Business Research, Volume 64, Issue 7, Pages 699-706

6. Armstrong, J.S. and Graefe, A. (2011), Predicting Elections from Biographical Information about Candidates: A Test of the Index Method, Journal of Business Research, Vol. 64(7). p. 699-706.

7. Cuzán, A. G. \& Bundrick, C. M. (2009), Predicting presidential elections with equallyweighted regressors in Fair's equation and the fiscal model, Political Analysis 17, 333-340. DOI: 10.1093/pan/mpp008

8. Simonton Dean K. (1993), Putting the Best Leaders in the White House: Personality, Policy, and Performance; Political Psychology, Vol. 14, No. 3, pp. 537-548

9. Petrocik, J. R. (1996), Issue ownership in presidential elections, with a 1980 case study, American Journal of Political Science, Vol. 40, No. 3, pp. $825-850$

10. Lau, R. R. \& Redlawsk, D. P. (1997). Voting correctly, American Political Science Review, Vol. 91, No. 3, 585-598

11. Nicholas R. Miller (1980), A New Solution Set for Tournaments and Majority Voting: Further GraphTheoretical Approaches to the Theory of Voting, American Journal of Political Science, Vol. 24, No. 1, pp. 68-96 
International Journal of Trend in Scientific Research and Development (IJTSRD) ISSN: 2456-6470

12. Wlezien, C. (2005), On the salience of political issues: The problem with 'most important problem', Electoral Studies, 24, 555-579. DOI:10.1016/j.electstud.2005.01.009

13. Matthew D. Atkinson, Ryan D. Enos and Seth J. Hill (2009), Candidate Faces and Election Outcomes: Is the Face-Vote Correlation Caused by Candidate Selection?, Quarterly Journal of Political Science, Vol. 4, pp. 229-249

14. Dawn Brancati (2011), Democracy Promotion: Citizens' Perceptions of Electoral Monitors,

15. T T Ram Mohan (2007), Reforming Indian politics, The Economics Times, Bennett, Coleman \& Co. Ltd

16. Graefe, A. and Armstrong, J. S. (2012), Forecasting Elections from Voters' Perceptions of Candidates' Ability to Handle Issues. Journal of Behavioral Decision Making. doi: 10.1002/bdm.1764

17. Divyanshu (2002), A blueprint for political reform in India, CRISIL Young Thought Leader 2002

18. Jennifer Corriero (2004), Role of Youth Survey, TakingITGlobal
19. Redlawsk, D. P. (2004), What voters do: Information search during election campaigns, Political Psychology, Vol. 25, No. 4, 595-610. DOI: $10.1111 / \mathrm{j} .1467-9221.2004 .00389 . x$

\section{Webliography}

20. http://currentgk.com/india/polity/constitution_indi an_polity.html

21. http://india.gov.in/govt/constitutions_india.php

22. http://forum.topnews.in/threads/4861-List-OfScams-In-India

\section{Books/e-Books}

23. HE A. P. J. Abdul Kalam, Book on "eGovernance Overview and Project Assessment", Chapter 1: A Vision of Citizen-centric eGovernance for India

24. Perri 6, Holistic government, Demos, London, ISBN 1898309043

25. Sk Khanna, Reforming Indian Political System, Commonwealth Publishers, 1999, ISBN 9788171695355

26. Key Competencies for Improving Local Governance, Volume 3: Concepts and Strategies, UN-HABITAT, ISBN 92-1-131731-2 